\title{
Presentación
}

\section{De la imagen a los contextos. Sobre las maneras de abordar e interpretar la producción visual en arqueología}

En este volumen se integra una primera parte de los trabajos presentados en el simposio "De la imagen a los contextos. Sobre las maneras de abordar e interpretar la producción visual en arqueología", realizado en agosto de 2016, en el marco del XIX Congreso Nacional de Arqueología Argentina, celebrado en San Miguel de Tucumán.

Aquella propuesta se orientaba a crear un espacio de análisis y discusión para la puesta en común de saberes y experiencias que, reunidos desde distintos lugares, se integraban en la arqueología de la imagen. El desafío fue centrar la mirada en el discurso visual que, generado a través de una variedad de prácticas y recursos creativos, se materializa en distintas morfologías, soportes expresivos y esferas socioespaciales, considerando las formas de abordar e interpretar las imágenes desplegadas en soportes fijos (rupestre, escultórico, arquitectónico), móviles (cerámica, óseo, lítico, metal, textil, ornamentación corporal), así como los contextos de vida en los que esas imágenes se constituyen (casas, cuevas, tumbas, caminos, campos, etc.).

Con esa finalidad, más de 20 expositores sudamericanos cruzaron temas, geografías (Noroeste, sierras centrales, pampa y Patagonia argentina, Patagonia y norte chilenos), miradas y búsquedas enfocando tanto los lineamientos teóricos como las herramientas metodológicas y técnicas empleados para el análisis del discurso plástico. Para nuestra satisfacción, muchos de los participantes de aquel simposio se sumaron a esta propuesta de publicación; fue necesario entonces organizar su edición en dos números. En esta primera entrega se incluyen 7 artículos centrados en el análisis de imágenes desplegadas en soportes rupestres y cerámicos.

En el primer artículo, Callegari, Spengler y de Acha analizan un tipo particular de expresiones visuales prehispánicas del norte de la provincia de La Rioja (Noroeste, Argentina): geoglifos o estructuras terraplenadas cubiertas con piedras de colores. A fin de avanzar en la comprensión del contexto de significación y su integración con las prácticas socio-espaciales las autoras proponen un acercamiento contextual que, además del relevamiento planimétrico y el análisis de sus características formales, toma en consideración las particularidades del entorno natural, el construido y su posible relación con otras materialidades localizadas en las inmediaciones.

Por su parte, Cordero, Muñoz y Artigas presentan los resultados del relevamiento sistemático de diferentes sitios con arte rupestre emplazados en el sector medio del río lbáñez (Patagonia central, Chile). A partir de la presentación de las características de los sitios, el análisis de 
las figuras en ellos desplegadas, las técnicas empleadas y las comparaciones con los grupos estilísticos definidos para el área del río Pinturas (Patagonia central, Argentina), los autores reflexionan en torno a la idea de estilo, la teoría de intercambio de información y la noción de memoria colectiva a fin de aproximarse a la comprensión del comportamiento de los grupos que vivieron en aquella zona durante el Holoceno.

El artículo de Nastri, Mirosnikov, Longo y Gandini compila el conjunto de casos de representaciones humanas pintadas en las mejillas de las urnas santamarianas desde fines del siglo XIX hasta la actualidad considerando que la observación de las características de estas figuras se revela como una vía de aproximación a las antiguas concepciones sobre la humanidad y los roles sociales durante el Período Intermedio Tardío en los Valles Calchaquíes (Noroeste, Argentina). Los autores realizan una primera clasificación de los motivos atendiendo a la forma del cuerpo, producto a su vez del tipo de atuendo o vestimenta usado por el personaje representado, contemplan las cantidades de tipos de vestimenta y sus combinaciones dentro de una misma cara y en una misma pieza y desarrollan ideas acerca de la función que las imágenes de personas pudieron tener en el seno de los antiguos sistemas de representaciones vigentes en los valles durante estos momentos.

A continuación, Recalde y Colqui analizan un segmento del repertorio temático que circuló en los soportes rupestres de la localidad arqueológica de Cerro Colorado (sierras del norte, centro de Argentina) durante el Período Prehispánico Tardío (ca. 400-1540 DC) haciendo énfasis específicamente en las figuras de animales no camélidos. Proponen una clasificación tipológica que, a partir del registro de rasgos anatómicos específicos, facilite la identificación de cada una de las especies allí presentes contemplando las regularidades sin perder de vista sus expresiones particulares. Dado que las autoras consideran que los animales constituyen un medio a través del cual las personas se relacionan con el paisaje, este análisis del modo en que se incorporaron al repertorio rupestre y por su medio al mundo social, les permite acercarse al rol que jugaron estas imágenes en la construcción y el mantenimiento de la memoria y la identidad.

El intensivo remontaje a partir de fragmentos, y la comparación de las piezas reconstruidas con vasijas completas de referencia les permitió a lucci y Wyndvelt abordar un grupo particular de ollas que no había sido trabajado sistemáticamente hasta el momento y cuyo registro es recurrente en el Valle de Hualfín (Catamarca, Noroeste, Argentina): las ollas con patas. En este artículo, las abordan a distintas escalas analíticas que incluyen su caracterización general, el análisis semiótico de la imagen modelada y el detalle de los contextos arqueológicos en que se recuperaron. Este múltiple abordaje les permite reconocer en ellas referencias claves a los camélidos, animales de fuerte presencia en la alfarería de épocas más tempranas y que, a partir de este caso y en contraposición con lo que se pensaba, parecen mantener su vigencia en la de momentos tardíos del valle. 
En el artículo escrito por Gheco, Gastaldi, Mastrangelo, Quesada, Marte y Tascón se presenta una metodología que vincula tres evidencias materiales documentadas en algunos de los abrigos del sitio arqueológico de Oyola (Catamarca, Noroeste, Argentina): las pinturas rupestres, los restos de fogones hallados en la excavación del piso y las marcas de hollín detectadas sobre las paredes. Esta propuesta novedosa les permite a los autores conectar la estratigrafía del sustrato de la cueva y la estratigrafía de las paredes y así relacionar los procesos de pintado de los paneles rupestres con las historias y actividades registradas en los pisos. A lo largo del artículo, logran ubicar estratigráficamente los diferentes paneles de motivos pintados y posicionar cronológicamente paneles y estratos que no tiene fechados radiocarbónicos directos abriendo, en simultáneo, múltiples posibilidades para integrar el arte rupestre al conjunto de prácticas sociales ejecutadas en estos espacios.

Por último, Gordillo y Basile proponen un ensayo metodológico que les permite discutir las relaciones existentes entre los universos expresivos correspondientes a dos momentos y lugares específicos: el Período Medio (ca. 600-1200 AD) en el Valle de Ambato y el Período de Desarrollos Regionales o Intermedio Tardío (ca. 1200-1400 AD) en la Región de Fiambalá (Catamarca, Noroeste, Argentina). Para abordar ambos discursos visuales, desplegados sobre soportes fijos (arte rupestre) y/o móviles (cerámica), emplearon criterios y categorías de análisis comunes que permitieron su caracterización y confrontación contemplando los repertorios visuales, sus modos de representación y los lugares en que estas imágenes se desplegaban (soportes y contextos).

Junto con presentar este volumen e invitar al lector a transitar los escenarios, reflexiones y propuestas desplegados por los autores y las autoras, queremos agradecer a todos los colegas que, a través de su asistencia o la presentación de sus ponencias o artículos, contribuyeron a enriquecer la discusión. Queremos también agradecer al Dr. Álvaro Martel quién ofreció su aguda mirada como comentarista del simposio y a los editores del Boletín por su interés en la temática y por ayudarnos a lograr que esta publicación llegue a buen puerto.

Mara Basile* Inés Gordillo**

\footnotetext{
* Instituto de las Culturas (IDECU) Universidad de Buenos Aires-CONICET Facultad de Filosofía y Letras Museo Etnográfico J.B. Ambrosetti

* * Instituto de Arqueología Facultad de Filosofía y Letras Universidad de Buenos Aires
} 